IZA DP No. 9017

Happy Moves? Assessing the Link Between Life Satisfaction and Emigration Intentions

Artjoms Ivlevs

April 2015 


\title{
Happy Moves? Assessing the Link Between Life Satisfaction and Emigration Intentions
}

\author{
Artjoms Ivlevs \\ University of the West of England, Bristol \\ and IZA
}

Discussion Paper No. 9017

April 2015

IZA

P.O. Box 7240

53072 Bonn

Germany

Phone: +49-228-3894-0

Fax: +49-228-3894-180

E-mail: iza@iza.org

Any opinions expressed here are those of the author(s) and not those of IZA. Research published in this series may include views on policy, but the institute itself takes no institutional policy positions. The IZA research network is committed to the IZA Guiding Principles of Research Integrity.

The Institute for the Study of Labor (IZA) in Bonn is a local and virtual international research center and a place of communication between science, politics and business. IZA is an independent nonprofit organization supported by Deutsche Post Foundation. The center is associated with the University of Bonn and offers a stimulating research environment through its international network, workshops and conferences, data service, project support, research visits and doctoral program. IZA engages in (i) original and internationally competitive research in all fields of labor economics, (ii) development of policy concepts, and (iii) dissemination of research results and concepts to the interested public.

IZA Discussion Papers often represent preliminary work and are circulated to encourage discussion. Citation of such a paper should account for its provisional character. A revised version may be available directly from the author. 


\title{
ABSTRACT
}

\section{Happy Moves? Assessing the Link Between Life Satisfaction and Emigration Intentions}

It has been shown that higher levels of subjective well-being lead to greater work productivity, better physical health and enhanced social skills. Because of these positive externalities, policymakers across the world should be interested in attracting and retaining happy and lifesatisfied migrants. This paper studies the link between life satisfaction and one's intentions to move abroad. Using survey data from 35 European and Central Asian countries, I find a Ushaped association between life satisfaction and emigration intentions: it is the most and the least life-satisfied people who are the most likely to express intentions to emigrate. This result is found in countries with different levels of economic development and institutional quality. The instrumental variable results suggest that higher levels of life satisfaction have a positive effect on the probability of reporting intentions to migrate. The findings of this paper raise concerns about possible 'happiness drain' in migrant-sending countries.

JEL Classification: F22, O15, P2

Keywords: $\quad$ subjective well-being, life satisfaction, emigration, transition economies

Corresponding author:

\author{
Artjoms Ivlevs \\ Department of Accounting, Economics and Finance \\ Bristol Business School \\ University of the West of England \\ Bristol BS16 1QY \\ United Kingdom \\ E-mail: a.ivlevs@uwe.ac.uk
}


"At the heart of every man there is an instinct of prosperity and greater happiness. Our ... emigrants, who are leaving for larger cities, either in Germany or America, are not pale, draining, hungry and desperate, but are strong, blooming, young men who are full of life and strength; and there are the most vigorous women. On the sad road out of their homeland they are not accompanied so much by despair but rather by expectations and the awareness of their own forces and strength."1

\section{INTRODUCTION}

The determinants of the individual emigration decision have long been a question of primary interest for academics and policy makers. A large and well-established literature has studied the role of socio-demographic, contextual and attitudinal variables in shaping the decision to migrate. A more recent literature has started to explore the role of subjective well-being, asking whether it is the most or the least happy ${ }^{2}$ people who are more likely to move abroad (Cai et al., 2014; Chindarkar 2014; Otrachshenko and Popova, 2014; Graham and Markowitz, 2011). ${ }^{3}$

There are several reasons why it is important to understand the relationship between subjective well-being and the decision to emigrate. First, local and national governments across the world have been increasingly considering and adopting subjective well-being as a key policy variable capturing individual welfare and societal progress (OECD, 2013; Office for National Statistics, 2013; Helliwell et al., 2013; Diener et al., 2009). If subjective wellbeing is an important determinant of the decision to emigrate, policy-driven changes in happiness may affect individual migration decisions and the ensuing migration flows. Second, it has been shown that higher levels of individual subjective well-being result in greater productivity (Oswald et al., 2015), creativity (Amabile et al., 2005; George and Zhou,

\footnotetext{
${ }^{1}$ A description of migration from Slovenia in the beginning of $20^{\text {th }}$ century, provided in 1906 by a Slovenian politician Anton Korošec (Drnovsec, 2009: 61).

${ }^{2}$ In this paper, I use the terms 'subjective well-being', 'happiness' and 'life satisfaction' interchangeably.

${ }^{3}$ The strand on subjective well-being and the decision to migrate is part of a broader literature on happiness and migration (see Simpson (2013) and International Organisation for Migration (2013) for an overview). Other directions in this literature have looked at whether migration experience makes people happier (Bartram, 2011; Bartram, 2013; Erlandhagen, 2011; Nikolova and Graham, 2015; Stillman et al., 2015) and whether migration affects the well-being of receiving and sending-country populations (Akay et al., 2014; Betz and Simpson, 2013; Borraz et al., 2008).
} 
2007), physical health (Diener and Chan, 2011), sociability, quality of social relationships, social capital, and social behaviour (De Neve et al., 2013; Guven, 2011), as well as a greater probability of getting hired and promoted and receiving higher levels of education and income (De Neve and Oswald, 2012). ${ }^{4}$ Therefore, if a country receives immigrants, it should be interested in getting a high proportion of happy people among them. Happier and, hence, more productive, healthy and sociable migrants will, arguably, put less pressure on the welfare state and integrate more successfully into the host society. However, the flip side of any 'happiness gain' for the migrant-receiving countries is 'happiness drain' for the migrantsending countries. The policymakers of the latter should be concerned about the outflow of happy people, as this may deprive them of the many positive externalities that happiness is associated with. Thus, similarly to human capital, happiness is a valuable resource that both migrant-receiving and sending countries may wish to acquire or retain, and a central question that policymakers may want to ask is whether it is the most or the least happy people who are more prone to migration.

Several micro-level studies have suggested that there is a negative association between subjective well-being and intentions or willingness to migrate. ${ }^{5}$ Otrashchenko and Popova (2014) use the Eurobarometer data to show that, in Central and Eastern Europe, people less satisfied with life are more likely to report intentions to migrate - both internationally and domestically. Graham and Markowitz (2011) and Chindarkar (2014) find that, in Latin America, subjective well-being and intentions to migrate are negatively correlated. Cai et al. (2014), using Gallup World Survey data for 116 countries, uncover a negative association between life satisfaction and desire to migrate internationally. A more mixed picture is obtained by Polgreen and Simpson (2011), who study the life satisfaction-emigration relationship at the country level and find that in relatively unhappy countries emigration rates fall as average country happiness increases, while the opposite is true for the relatively happy countries; the highest emigration rates are, thus, observed in the most and the least happy countries.

This paper continues the investigation of the relationship between subjective well-being and the decision to emigrate, making several contributions to the literature. First, on the theoretical front, I discuss the channels that link subjective well-being and the emigration decision and reflect on how happiness may fit into the Neoclassical model of migration.

\footnotetext{
${ }^{4}$ See De Neve et al. (2013) for an overview of the effects of subjective well-being on objective outcomes.

${ }^{5}$ See Ivlevs (2014) for a detailed review of this literature.
} 
Second, I review the relationship between life satisfaction and emigration intentions. The empirical analysis is based on a large and underexplored dataset - the "Life in Transition-2" survey, administered in 2010 by the European Bank for Reconstruction and Development and the World Bank in 35 European and Central Asian countries. Contrary to previous research, I find strong evidence for a U-shaped association between the two phenomena: the greatest intentions to move abroad are reported by people who are the most and the least satisfied with their lives. This relationship changes little with the countries' economic and institutional development and different cultural contexts. Third, while the existing literature provides important insights on the association between life satisfaction and desire to emigration, little is known about the effect of subjective well-being on the emigration decision. One of the objectives of this paper is to address the issues of endogeneity that may arise in the relationship between the two variables. Using instrumental variable analysis, I find that life satisfaction increases the probability of reporting intentions to migrate.

The empirical analysis of this paper is based on the use of life satisfaction to capture subjective well-being, and emigration intentions to capture the emigration decision. Both measures can be subject to criticism. First, unlike the objective, clearly quantifiable metrics of most variables used in economics, life satisfaction and happiness are self-reported and subjective constructs. They can be understood differently by similar people within and between countries, which makes it potentially difficult to interpret interpersonal comparisons of happiness indices (Di Tella and MacCulloch, 2006). However, the subjective measures of well-being have been extensively validated via psychological and brain-scan research, and shown to be reliable, consistent (across time and space) and comparable measures of individual well-being (Frey and Stutzer, 2002; Layard, 2005; Graham, 2009; Helliwell and Barrington-Leigh, 2010; Diener et al., 2012). Given the increasing importance of happiness for policy, there has recently been an explosion in research on subjective well-being among the economists (see, e.g., MacKerron (2012) for an overview), who have been more willing to accept happiness as a manifestation of utility and well-being.

Another note of caution concerns the use of emigration intentions data as a proxy for actual emigration. Although it is not without criticism - there is no guarantee that intentions will be followed by an actual move - longitudinal studies have shown that emigration intentions are 
a good predictor of actual future emigration. ${ }^{6}$ Creighton (2013) showed that, in Mexico, aspirations to move internally and internationally explain the subsequent moves. Van Dalen and Henkens (2013) found that one-third of native Dutch residents who had stated an intention to move abroad actually emigrated within the following five years. ${ }^{7}$ Böheim and Taylor (2002) showed that the propensity to move internally in the UK is three times higher for those who earlier expressed a preference to move than those who did not. At a theoretical level, De Jong (1999, 2000) argues that the intentions to move are the primary determinant of the migration behaviour and Burda et al. (1998) posit that intentions are a monotonic function of the variables which motivate migration. A specific advantage of using migration intentions data is that it avoids the sample selection issues that arise from the use of the data on actual immigrants collected by host countries, for instance, when immigration policies are designed to attract more (or less) skilled migrants (Liebig and Sousa-Poza, 2004). ${ }^{8}$ It should also be remembered that the migrant - once migrated - can no longer be observed in the source country. Tracking down each migrant after the arrival in the host country and obtaining large representative samples of immigrants would be costly and problematic (see, e.g., Erlinghagen, 2011); at the same time, interviewing large numbers of prospective migrants in home countries is more cost-effective.

The paper proceeds as follows. Section two reflects on the theoretical channels linking subjective well-being and the emigration decision. Section three presents data, variables and estimation strategy. Section four presents the empirical results of the models which do not account for endogeneity. Section five deals with the issues of endogeneity. Section six reports the results of the robustness and sensitivity checks, followed by a conclusion.

\section{THEORETICAL CONSIDERATIONS}

It is common for economists and other social scientists to view the emigration decision as an investment: utility-maximising people go abroad if the benefits of doing so outweigh the costs. ${ }^{9}$ In this Neoclassical framework, utility is typically represented by income streams that

\footnotetext{
${ }^{6}$ See, e.g., Ivlevs (2013), Ivlevs and King (2012), and references therein, for recent empirical studies using emigration intentions data to determine the profile of future migrants.

${ }^{7}$ However, this finding also indicates that two thirds of those who expressed an intention to move abroad did not do so.

${ }^{8}$ However, the population of the origin country is also a selected one, as it excludes people who have already emigrated.

${ }^{9}$ Note that the focus of this paper is on voluntary (and not forced/refugee) migration.
} 
can be earned at home and abroad, and the main prediction is that poorer people are more likely to migrate as they gain most from migration. However, income is not the only thing that people may wish to maximise; subjective well-being can be easily incorporated into the model. Assuming that 1) instead of income people maximise happiness and 2) people believe that higher levels of happiness can and will be achieved abroad, the framework predicts that unhappy people are more likely to migrate as they have the most to gain (in terms of happiness) from migration.

It should be noted that the prediction that unhappy people are the most likely to emigrate depends critically on the assumption that people believe that higher levels of happiness are achievable abroad. While one may judiciously consider that more money can be earned abroad than at home, it is debatable whether people in migration-sending countries necessarily assume that emigration results in happier lives. Prospective migrants may learn through friends, relatives and media - about the foreign-life experiences of existing migrants, and these experiences may convey signals of both happiness and unhappiness. For example, a survey conducted in Latvia in 2013 suggests that people are almost equally split on the question of whether migration leads to happier lives. When asked, "Disregarding financial considerations, do you think that Latvian migrants, while living abroad, are happier than if they had lived in Latvia?”, 15\% of the respondents said 'yes', 27\% said 'probably yes', 28\% said 'probably no', 14\% said 'no', and 16\% found it difficult to answer (DNB Banka, 2013). ${ }^{10}$ Unfortunately, it is not known what the distribution of these answers would be for the subsample of prospective migrants (the question on emigration intentions was not asked in this survey); there is also no guarantee that the perceived happiness effects of emigration are the same in Latvia and other parts of the world. Nonetheless, this survey evidence warrants caution when assuming that people believe that migration leads to happier lives.

Another critical note about the assumption that migration makes people happier is that it is in conflict with the set-point theory of subjective well-being. This theory posits that individual happiness changes in face of major life events (marriage, birth of a child, death of a partner) but returns to an individual-specific happiness trend in the long run. There is no guarantee, however, that prospective migrants are familiar with this theory or that the theory holds in all life situations (see, e.g., Headey, 2010). Prospective migrants may continue to expect, rightly or wrongly, that migration results in happier lives.

\footnotetext{
${ }^{10}$ A survey of 1003 respondents was part of the regular 'DNB Latvia Barometer', conducted by the DNB Bank in March 2013. The survey is representative of the country’s regional, age, gender and ethnicity distributions.
} 
Returning to the predictions of the happiness-centred Neoclassical model of migration, interesting implications arise from the analysis of the costs of migration. In the traditional, income-centred version of the model the poorest people often do not emigrate because a certain level of income is necessary to cover migration costs. By analogy, one could hypothesize that a certain level of happiness is necessary to trigger migration. Arguably, in order to cross borders and adapt to new environments, people need to be optimistic, confident, open-minded and sociable. As these characteristics are likely to be related to happiness, a positive association between happiness and emigration might be expected.

Some supporting evidence for the conjecture that migrants share certain personality characteristics that could go hand-in-hand with happiness comes from the psychology literature. Ek et al. (2008) find that rural-to-urban migrants in Finland are more optimistic and satisfied with life than the non-migrants. Boneva and Frieze (2001) find that prospective migrants in Eastern Europe have higher achievement motivation (expressed, for example, by willingness to surpass one's own standard of excellence and to do something challenging and unique) and power motivation (desire to be recognised and to impress others) than the nonmigrants. Polgreen and Simpson (2011) also argue that happier people tend to be more optimistic, adventurous and willing to pursue new opportunities abroad, which helps explain their finding that, in relatively happy countries, emigration rates increase with average happiness. Thus, it is not unreasonable to assume that migrants are positively selected on happiness, although happiness here may simply be capturing the influence of other factors optimism, confidence, need for challenge and recognition - which are often unobservable and rarely controlled for in the economists' and other social scientists' analyses of the emigration decision.

Another way to conceive a positive relationship between happiness and the emigration decision is to return to the traditional version of the Neoclassical model and assume that people maximise income rather than happiness (for example, because people do not believe that migration results in happier lives, but they still associate migration with higher income and want to maximise it). Now, if happy people are also aware that they are more productive, creative, cooperative, sociable and, indeed, have better chances of being hired, promoted and receiving higher income than unhappy people (De Neve et al., 2013; De Neve and Oswald, 2012), those with high levels of happiness will be more confident about their earnings potential abroad and, therefore, more likely to consider emigration than the less happy people 
in otherwise similar circumstances. Arguably, this positive link between happiness and migration intentions would be more relevant for poorer countries, where the income gains from migration are greater.

One could also argue that in countries where individual development is hampered by ineffective governments and limited upward mobility, more ambitious, entrepreneurial and freedom-loving people consider emigration as a strategy to improve their situation. If these personal characteristics are correlated with happiness, one may expect a stronger positive association between happiness and emigration in countries where institutions are inefficient and possibilities for personal and career growth low. In contrast, in more open societies, there may be no need for happy people to leave.

In sum, both a negative and a positive relationship between happiness and the emigration decision can be conceived. It is also possible that the relationship between the two variables is stronger in poorer countries, as well as countries with weak institutions and limited possibilities for personal and career growth. These theoretical propositions represent testable hypotheses and will be confronted with data in the next section. In addition, I will test whether there is a non-linear (quadratic) relationship between subjective well-being and the desire to emigrate. It is possible that particular theoretical channels work only for a specific range of the subjective well-being distribution. For example, for relatively unhappy people, increases in happiness might be associated with a lower willingness to move - consistently with the happiness-enhanced Neoclassical model. However, once a particular happiness threshold level is attained, increases in happiness might lead to a greater desire to emigrate possibly reflecting the role of optimism (Polgreen and Simpson, 2011) and motivation (Boneva and Frieze, 2001) in shaping the emigration decision.

Lastly, it is worth noting that the discussion of the theoretical channels presented in this section should be viewed as the first steps towards the development of a more definite model linking happiness and the emigration decision. Before such a model can be developed, several questions need to be answered: Do people maximise income or happiness (or both) when they take their decision to move abroad? Do prospective migrants believe that migration leads to happier lives? What are the limits for distinguishing happiness from other personality traits, such as optimism, open-mindedness, ambition, entrepreneurialism, need for challenge and recognition, which are potential confounding factors in the happinessemigration relationship? Are happy people aware that they have greater earnings potential 
than unhappy people and how does this affects their emigration decision? Answers to these questions are instrumental to develop firm foundations behind the theoretical model explaining happiness-emigration decision relationship; this is left for future research.

\section{DATA, VARIABLES AND EMPIRICAL MODEL}

\section{Data}

Data for this study come from the "Life in Transition 2" survey, conducted by the European Bank for Reconstruction and Development (EBRD) and the World Bank in autumn 2010. Thirty five European and Central Asian countries participated in the survey: fourteen successor states of the former USSR (Armenia, Azerbaijan, Belarus, Estonia, Georgia, Kazakhstan, Kyrgyzstan, Latvia, Lithuania, Moldova, Russia, Tajikistan, Ukraine, Uzbekistan; Turkmenistan did not take part in the survey), seven successor states of former Yugoslavia (Bosnia and Herzegovina, Croatia, FYR of Macedonia, Kosovo, Montenegro, Serbia, Slovenia), Albania, Bulgaria, Czech Republic, Hungary, Mongolia, Poland, Romania, Slovakia, Turkey, as well as five Western European countries (France, Germany, Italy, Sweden and the UK).

The nationally representative samples consisted of 1,000 respondents, aged 18 and above, per country (1,500 respondents in the case of Russia, Ukraine, Uzbekistan, Serbia, Poland and the UK). In each country, the households were selected according to a two-stage clustered stratified sampling procedure. In the first stage, the frame of primary sampling units was established using information on local electoral territorial units. In the second stage, a random walk fieldwork procedure was used to select households within primary sampling units. Steves (2011) provides the survey summary, including detailed information on survey design and implementation methodology.

\section{Dependent variable: emigration intentions}

I proxy the emigration decision with a dichotomous variable emigration intentions, which draws on the question, "Do you intend to move abroad in the next 12 months?” (possible answers 'yes' or 'no'). Overall, $4.8 \%$ of the respondents said they intended to move abroad in 
the following 12 months, with the proportion ranging from $0.6 \%$ in Germany to $23 \%$ in Albania.

The respondents were also asked a question "Would you be willing to move abroad for employment reasons?”, with possible answers 'yes’ or 'no', from which I construct a binary variable willingness to migrate. I use it to check the robustness of my results, but refrain from using it as the main dependent variable. Emigration intentions is preferred, as the question used to construct it is unambiguous, and the specified time frame (12 months) provides respondents an additional focus. In contrast, the question used to construct willingness to migrate is more vague and can be interpreted in different ways: some respondents might think of their general predisposition to migration, while others might think it is a hypothetical question and report their likelihood of moving abroad is if a specific need to do so arises.

\section{Main regressor: life satisfaction}

Respondents' subjective well-being is captured by the question, “All things considered, how satisfied or dissatisfied are you with your life as a whole these days? Please answer on a scale from 1 to 10, where 1 means completely dissatisfied and 10 means completely satisfied”. The resulting variable life satisfaction is a standard measure of subjective well-being in the literature, and is likely to represent its cognitive evaluation. ${ }^{11}$

The question’s loosely defined time frame (“these days”) may represent a concern for this study. A typical rationale for including "these days" in the question is to discount any spontaneous deviations in subjective well-being at the day of the interview and to make respondents take a longer term perspective on their life satisfaction. However, it is not clear how a potential change in life satisfaction due to the prospect of migration would fit into “these days” time frame. Respondents considering emigration may be temporarily off their 'normal', longer-term life satisfaction levels. Instrumental variable analysis, presented in section five of this paper, represents a partial solution to this issue.

\footnotetext{
${ }^{11}$ The Life in Transition-2 survey does not contain a question on happiness - a hedonic/ emotional (rather than cognitive) evaluation of subjective well-being. This is unfortunate, as happiness could have been used to check the robustness of the econometric results. Note, however, that there is no obvious reason to prefer one measure of wellbeing to the other; where available, happiness and life satisfaction are highly correlated and tend to produce almost identical results (Simpson, 2013).
} 


\section{Control variables}

To isolate the effect of life satisfaction on emigration intentions, one must control for potential confounders - variables potentially affecting subjective well-being, emigration intentions, or both. Previous literature has shown that factors such as gender, age, family composition, ethnic/linguistic minority status, education, income and employment status are important determinants of both subjective well-being and the emigration decision. Therefore, I include dummy variables for gender, five age groups, five marital status groups (single, married/ living with a partner, divorced/separated, widow), having children, three education levels (primary, secondary, tertiary) and being employed. The minority status is captured by the information on the respondent's mother tongue - the linguistic minority dummy is equal to 1 if it is different from the respondent's country of residence state/official language(s). Dummy variables for three types of settlement (rural, urban, metropolitan) are also included.

Income is a crucial control variable potentially affecting both the decision to migrate and life satisfaction. Unfortunately, the survey does not contain information on respondent or household actual income. ${ }^{12}$ Therefore, I consider different proxies for household income. First, I use information on household assets (car, secondary residence, bank account, debit card, credit card, mobile phone, computer and internet access at home) to create a wealth index using principal components. Second, I use information on where respondents thought they were on a ten-step income ladder, where the first (tenth) step captures the poorest (richest) $10 \%$ of the country. While this variable may suffer from subjectivity bias (there is no guarantee that everyone imagines the ten-step income ladder in the same way), it is important to recognise that a perception of own income, especially relative to one's reference group, which can well be a country, may be an important determinant of both migration (Stark and Taylor, 1991) and life satisfaction (Clark et al., 2008). Third, I include a variable financial satisfaction, constructed from the question, “All things considered, I am satisfied with my financial situation as a whole" (five possible answers ranging from "strongly disagree” (1) to "strongly agree” (5)). As satisfaction with financial situation has been shown to be a strong predictor of life satisfaction, especially in poorer countries (Oishi et al., 1999), including a question on financial satisfaction is likely to remove some variation in the main

\footnotetext{
${ }^{12}$ The survey contains information on household monthly expenditure on different goods (food, utilities, transport, education, health, clothing and durable goods), as well as information on household monthly savings. I use this information to create a total expenditure and savings adult equivalence variable. Closer inspection of this variable revealed a 'don't know'/ non-response rate of $46 \%$ and it was decided not to use it because of the huge loss in information this would cause.
} 
regressor (life satisfaction). However, consistently with the theoretical discussion presented in the previous section, I want to separate subjective well-being from income and variables related to it. This said, in the robustness checks section (see the online appendix), I comment on how the results change when the satisfaction with financial situation control is excluded from the analysis.

A particular challenge is presented by finding a proxy for migrant networks - a crucial driver of the emigration decision. Unfortunately, only those respondents who said they intended to emigrate in the following 12 months were asked whether they had friends or relatives in the place they planned to move to. This information cannot be used to construct a networks dummy, as it would be conditioned by the dependent variable. Instead, I use all the information which can indicate indirectly that a respondent might have family or friends connections abroad. In the survey section on the impacts of the global economic crisis, the respondents were asked whether, in the two years prior to the interview, they had experienced a fall in remittances and a household member had returned from working abroad. I construct a migrant networks dummy which is equal to 1 if at least one of the following is true: 1 ) respondent's household experienced a crisis-related fall in remittances; and 2) a household member returned from abroad due to the crisis. With the average of 0.14 , this variable represents a lower bound of the intensity of migrant networks.

I also want to control for the respondents' health status, as previous literature suggests that good health has a strong positive association with subjective well-being (MacKerron, 2012; Diener and Chan, 2011); in addition, it could be argued that good health matters for migration. The respondents were asked, “How would you assess your health?” Possible answers "very good” and "good” are coded into a good health dummy, "very bad” and "bad” into a bad health dummy, with "medium” health remaining the reference category. Concerns similar to those expressed in the case of financial satisfaction variable also apply here: the inclusion of health status will remove variation from the life satisfaction variable. However, I consider health status as an independent driver of emigration and explicitly want to separate it from life satisfaction.

Finally, to control for all possible country-wide influences on the emigration decision and life satisfaction, I include country dummies. This will also ensure that the analysis captures within-country individual-level relationships between the variables of interest. 


\section{Empirical model}

Emigration intentions of individual $i$ from country $j$ can be expressed as follows:

$$
\begin{aligned}
& \text { emigration intentions }_{i j}=\quad \alpha_{0}+\alpha_{1} \text { life satisfaction }_{i j}+ \\
& \beta \text { (individual controls } \\
& i j)+ \\
& \delta\left(\text { country fixed effects }_{j}\right)+ \\
& \text { unobserved error term } \\
& \text { ij }
\end{aligned}
$$

where $\alpha_{0}, \alpha_{1}, \beta$ and $\delta$ are parameters/ parameter vectors to be estimated, and individual controls are the variables discussed in the previous sub-section.

In addition, to test for possible quadratic effects, I estimate a second model which includes the linear and squared terms of the life satisfaction variables:

$$
\begin{aligned}
& \text { emigration intentions }_{i j}=\quad \alpha_{0}+\alpha_{1} \text { life satisfaction }_{i j}+\alpha_{2} \text { life satisfaction }_{i j}{ }^{2}+ \\
& \left.\beta \text { (individual controls } s_{i j}\right)+ \\
& \left.\delta \text { (country fixed effects }{ }_{j}\right)+ \\
& \text { unobserved error term } i j
\end{aligned}
$$

Individuals older than 64 are excluded from the analysis, as, generally, they have very low propensities to migrate. In all estimations, I adjust the standard errors for heteroscedasticity and cluster them at the locality (village/ town/ city) level, and apply within-country population weights available from the survey dataset.

Given the binary nature of the dependent variable, I have estimated the models with binary probit as well as OLS. As the two approaches produced very similar results, I report the OLS estimates, which are easier to interpret. The binary probit results are available on request.

\section{RESULTS: CORRELATIONAL EVIDENCE}

In this section, I report evidence based on partial correlations, i.e., the results of the multivariate regressions which do not account for the endogeneity of the life satisfaction variable (the endogeneity issues are addressed in the next section). Column 1 of Table 1 reports the results of model (1). The coefficient of the regressor of interest, life satisfaction, is a negative and significant at $10 \%$. Keeping other factors constant, one step on the 1 to 10 life satisfaction scale is associated with a 0.0016 decrease in the dependent variable. This model, 
thus, would suggest that it is the least life-satisfied people who are more likely to report intentions to migrate, although the difference in the probability of reporting emigration intentions between people who are the least and the most satisfied with their lives is rather small: 1.6 percentage points.

A different picture emerges if the squared term of the life satisfaction variable is also included in the regression (column 2 of Table 1). Now both life satisfaction and its square are highly significant. The negative coefficient of the former and the positive coefficient of the latter imply a U-shaped relationship between life satisfaction and the probability of reporting emigration intentions, with the turning point corresponding to 6.20 units of life satisfaction somewhat higher than the life satisfaction sample mean (5.58). This result implies that for relatively low levels of life satisfaction the likelihood of reporting intentions to migrate decreases with life satisfaction and for relatively high levels of life satisfaction the likelihood of reporting intentions to migrate increases with life satisfaction.

The coefficients of the socio-demographic controls are largely in line with expectations: women, older people and the less healthy are less likely express desire to migrate, while the single and those with migrant networks are more likely to do so. Wealth index has a positive association with emigration intentions, which could be explained by the necessity to have initial capital to cover migration costs. Satisfaction with financial situation appears to be the only income-related variable which is negatively correlated with emigration intentions. Linguistic minorities also appear more prone to migration, which can be explained by the various types of disadvantages that minorities face in source countries and is consistent with previous literature (see, e.g., Ivlevs, 2013). 
Table 1. Life satisfaction and intentions to move abroad, OLS results

\begin{tabular}{|c|c|c|}
\hline & \multicolumn{2}{|c|}{$\begin{array}{l}\text { Intentions to move } \\
\text { abroad }(0 / 1)\end{array}$} \\
\hline & $(1)$ & $(2)$ \\
\hline Life satisfaction (1 - low, ... 10 - high) & $-0.0016^{*}$ & $-0.0191 * * *$ \\
\hline Life satisfaction squared/100 & - & $0.154 * * *$ \\
\hline Female & $-0.025 * * *$ & $-0.025 * * *$ \\
\hline \multicolumn{3}{|l|}{ Age group } \\
\hline $18-24$ & $0.020 * * *$ & $0.020 * * *$ \\
\hline $25-34$ & $0.009 * *$ & $0.009 * *$ \\
\hline $35-44$ & Ref. & Ref. \\
\hline $45-54$ & $-0.016^{* * *}$ & $-0.016 * * *$ \\
\hline $55-64$ & $-0.019 * * *$ & $-0.019 * * *$ \\
\hline \multicolumn{3}{|l|}{ Marital status } \\
\hline Single & $0.030 * * *$ & $0.030 * * *$ \\
\hline Married/ relationship & Ref. & Ref. \\
\hline Divorced/separated & $0.017 * * *$ & $0.017 * * *$ \\
\hline Widow & 0.006 & 0.006 \\
\hline Has children & -0.003 & -0.003 \\
\hline Linguistic minority & $0.022 * * *$ & $0.022 * * *$ \\
\hline \multicolumn{3}{|l|}{ Education } \\
\hline Primary & -0.003 & -0.003 \\
\hline Secondary & Ref. & Ref. \\
\hline Tertiary & 0.001 & 0.001 \\
\hline Wealth index & $0.005^{* * *}$ & $0.005^{* * *}$ \\
\hline Perceived income decile (1 - low.. 10 - high) & -0.001 & -0.000 \\
\hline Satisfied with financial situation ( 1 - low.. 5 - high) & $-0.003 *$ & $-0.003 *$ \\
\hline Employed & -0.001 & -0.001 \\
\hline \multicolumn{3}{|l|}{ Type of settlement } \\
\hline Rural & -0.003 & -0.002 \\
\hline Urban & Ref. & Ref. \\
\hline Metropolitan & -0.007 & -0.008 \\
\hline \multicolumn{3}{|l|}{ Health } \\
\hline Bad & -0.006 & $-0.009 *$ \\
\hline Medium & Ref. & Ref. \\
\hline Good & 0.002 & 0.002 \\
\hline Migrant networks & $0.024 * * *$ & $0.024^{* * *}$ \\
\hline Country fixed effects & Yes & Yes \\
\hline Observations & 30567 & 30567 \\
\hline $\mathrm{R}^{2}$ & 0.064 & 0.065 \\
\hline$F$ test $(p>F)$ & 0.000 & 0.000 \\
\hline
\end{tabular}

Notes: *** $\mathrm{p}<0.01, * * \mathrm{p}<0.05, * \mathrm{p}<0.1$. Robust standard errors, clustered at locality level, used to calculate regressors' statistical significance. See online appendix for full econometric output.

Next, drawing on the discussion of theoretical channels which suggested that the relationship between happiness and emigration intentions might depend on country characteristics, I estimated the two models for countries with different levels of economic development and institutional quality. Table 2 shows the results when the models are estimated for the lowincome, lower-middle income, upper-middle income and high income countries. The findings 
suggest that national per capita income does not have an impact on the association between life satisfaction and intentions to migrate. In the linear model, the coefficient of life satisfaction is negative but statistically insignificant in all country groups. In the quadratic model, all country groups exhibit a U-shaped relationship between life satisfaction and emigration intentions, with the linear and quadratic terms significant at $1 \%$ in the uppermiddle and high-income countries and at $1-10 \%$ in the low and lower-middle-income countries. ${ }^{13}$ There is also little country-group variation in the values of life satisfaction at which emigration intentions are at their minimum: the turning points range from 5.55 in the lower-middle income countries to 6.66 in low-income countries. In all country groups, these values are above, but still relatively close to, the average levels of life satisfaction. Thus, the association between intentions to migrate and life satisfaction appears to be U-shaped regardless of the national income per capita.

Table 2. Life satisfaction and intentions to move abroad, by country income level; OLS results

\begin{tabular}{|c|c|c|c|c|c|c|c|c|}
\hline \multirow[b]{2}{*}{ Life satisfaction } & \multicolumn{2}{|c|}{$\begin{array}{l}\text { Low-income } \\
\text { countries }\end{array}$} & \multicolumn{2}{|c|}{$\begin{array}{l}\text { Lower-middle } \\
\text { income countries }\end{array}$} & \multicolumn{2}{|c|}{$\begin{array}{l}\text { Upper-middle } \\
\text { income countries }\end{array}$} & \multicolumn{2}{|c|}{$\begin{array}{l}\text { High-income } \\
\text { countries }\end{array}$} \\
\hline & -0.0046 & $-0.0517 * * *$ & -0.0000 & $-0.0151 *$ & -0.0020 & $-0.0170 * * *$ & -0.0011 & $-0.0161 * * *$ \\
\hline Life satisfaction squared/100 & - & $0.388 * *$ & - & $0.136^{*}$ & - & $0.139 * * *$ & - & $0.125 * * *$ \\
\hline Individual controls & Yes & Yes & Yes & Yes & Yes & Yes & Yes & Yes \\
\hline Country-fixed effects & Yes & Yes & Yes & Yes & Yes & Yes & Yes & Yes \\
\hline \multicolumn{9}{|l|}{ Life satisfaction } \\
\hline Turning point & - & 6.66 & - & 5.55 & - & 6.11 & - & 6.44 \\
\hline Sub-sample average & - & 5.22 & - & 5.16 & - & 5.20 & - & 6.37 \\
\hline Observations & 1,786 & 1,786 & 7,420 & 7,420 & 11,293 & 11,293 & 10,068 & 10,068 \\
\hline Number of countries & 2 & 2 & 8 & 8 & 13 & 13 & 12 & 12 \\
\hline $\mathrm{R}^{2}$ & 0.059 & 0.066 & 0.065 & 0.065 & 0.057 & 0.059 & 0.026 & 0.028 \\
\hline$F$ test $(p>F)$ & 0.040 & 0.018 & 0.000 & 0.000 & 0.000 & 0.000 & 0.000 & 0.000 \\
\hline
\end{tabular}

Notes: *** $\mathrm{p}<0.01, * * \mathrm{p}<0.05, * \mathrm{p}<0.1$. Robust standard errors, clustered at locality level, used to calculate regressors' statistical significance. Full econometric output available on request.

Next, I want to test the conjecture that happy people are less likely to emigrate from countries with more efficient and open regimes, where possibilities for personal and professional growth are more abundant. To do this, I estimate the models for countries with different

\footnotetext{
${ }^{13}$ There are only two countries in the low-income group: Kyrgyzstan and Tajikistan. Combining this group with lower-middle income countries produces a negative and statistically insignificant coefficient of the life satisfaction variable in the linear model, and a U-shaped relationship, with both the linear and squared term significant at $1 \%$, in the quadratic model.
} 
levels of institutional quality. As a measure institutional quality, I use six World Bank World Governance Indicators - 1) voice and accountability; 2) political stability and the absence of violence; 3) government effectiveness; 4) regulatory quality; 5) rule of law; and 6) control of corruption - from which I construct, with principal components, an index of institutional quality. I then split the countries into four groups, which correspond to increasing levels of institutional quality and are comparable in terms sample size and the number of countries included (see online appendix for the distribution). The results, shown in Table 3, provide little support for the conjecture that happy people are less likely to emigrate from countries with better institutions. A U-shaped relationship between life satisfaction and emigration intentions is supported in all four country groups, implying that emigration intentions decrease with life satisfaction for relatively life-unsatisfied people and increase for relatively life-satisfied people (the latter is particularly relevant for countries with the highest quality institutions, where the turning point lies to the left of the sample mean). In the linear model, the coefficient of life satisfaction is insignificant in countries with low, lower-middle and high-quality institutions (and positive in the two latter cases). It is, however, negative and significant at $1 \%$ in the upper-middle quality institutions specification. Considering which model - linear or quadratic - is a better fit for this country group, the Wald test suggests that the inclusion of the life satisfaction squared term is strongly justified $(F=17.88$; $p=0.000)$; the quadratic relationship therefore appears to be a better fit than the linear model. 
Table 3. Life satisfaction and intentions to move abroad, by quality of institutions; OLS results

\begin{tabular}{|c|c|c|c|c|c|c|c|c|}
\hline \multirow[b]{3}{*}{ Life satisfaction } & \multicolumn{8}{|c|}{ Quality of institutions } \\
\hline & \multicolumn{2}{|c|}{ Low } & \multicolumn{2}{|c|}{ Lower-middle } & \multicolumn{2}{|c|}{ Upper-middle } & \multicolumn{2}{|c|}{ High } \\
\hline & -0.0027 & $-0.0162 * *$ & 0.0008 & $-0.0179 * *$ & $-0.0048 * * *$ & $-0.0293 * * *$ & 0.0002 & $-0.0109 * *$ \\
\hline $\begin{array}{l}\text { Life satisfaction } \\
\text { squared/100 }\end{array}$ & - & $0.117^{* *}$ & - & $0.173^{* *}$ & - & $0.221 * * *$ & - & $0.0937 * *$ \\
\hline Individual controls & Yes & Yes & Yes & Yes & Yes & Yes & Yes & Yes \\
\hline Country-fixed effects & Yes & Yes & Yes & Yes & Yes & Yes & Yes & Yes \\
\hline \multicolumn{9}{|l|}{ Life satisfaction } \\
\hline Turning point & - & 6.92 & - & 5.17 & - & 6.62 & - & 5.81 \\
\hline Sub-sample average & - & 5.25 & - & 5.11 & - & 5.58 & - & 6.43 \\
\hline Observations & 8,006 & 8,006 & 7,921 & 7,921 & 7,387 & 7,387 & 7,253 & 7,253 \\
\hline Number of countries & 8 & 8 & 9 & 9 & 9 & 9 & 9 & 9 \\
\hline $\mathrm{R}^{2}$ & 0.052 & 0.053 & 0.064 & 0.065 & 0.051 & 0.055 & 0.027 & 0.029 \\
\hline$F$ test $(p>F)$ & 0.000 & 0.000 & 0.000 & 0.000 & 0.000 & 0.000 & 0.000 & 0.000 \\
\hline
\end{tabular}

Notes: $* * * \mathrm{p}<0.01, * * \mathrm{p}<0.05, * \mathrm{p}<0.1$. Robust standard errors, clustered at locality level, used to calculate regressors' statistical significance. Full econometric output available on request.

In a last country-group sensitivity check, I run the models for different geo-political blocs: 1) Baltics (Estonia, Latvia, Lithuania), 2) Balkans (Albania, Bosnia and Herzegovina, Bulgaria, Croatia, FYR Macedonia, Kosovo, Montenegro, Romania, Serbia), 3) Caucasus (Armenia, Azerbaijan, Georgia), 4) Central Asia (Kazakhstan, Kyrgyzstan, Mongolia, Tajikistan, Turkey, Uzbekistan), 5) Central Europe (Czech Republic, Hungary, Poland, Slovakia, Slovenia), 6) the rest of ex-USSR (Belarus, Moldova, Ukraine, Russia), and 7) Western Europe (France, Germany, Italy, Sweden, the UK). The U-shaped relationship between life satisfaction and emigration intentions is supported in the Balkans, Central Asia, Central Europe and Western Europe (Panel B of Table 3A); these four country groups represent 71\% of countries participating in the survey. In the Baltics and the Caucasus (17\% of countries), the linear model (with a negative life satisfaction variable) provides a better fit than the quadratic model (Panel A of Table 3A). In the rest of ex-USSR (11\% of countries), there appears to be no relationship between life satisfaction and intentions to migrate. It is difficult to find an explanation for these country-group differences: the U-shaped relationship holds in such economically, politically, socially and culturally diverse regions as Central Asia and Western Europe. One can notice, however, that the absence of the U-shaped relationship is found in the former republics of the USSR with relatively low average levels of life satisfaction. 
Table 4. Life satisfaction and intentions to move abroad, by geo-political bloc; OLS results

\begin{tabular}{|c|c|c|c|c|c|c|c|}
\hline & Baltics & Balkans & Caucasus & Central Asia & $\begin{array}{l}\text { Central } \\
\text { Europe }\end{array}$ & $\begin{array}{l}\text { Rest of ex- } \\
\text { USSR }\end{array}$ & $\begin{array}{l}\text { Western } \\
\text { Europe }\end{array}$ \\
\hline \multicolumn{8}{|l|}{ A. } \\
\hline Life satisfaction & $-0.0063 *$ & 0.0007 & $-0.0053 *$ & -0.0032 & -0.0011 & -0.0011 & -0.0004 \\
\hline $\mathrm{R}^{2}$ & 0.060 & 0.073 & 0.044 & 0.048 & 0.026 & 0.048 & 0.019 \\
\hline \multicolumn{8}{|l|}{ B. } \\
\hline Life satisfaction & -0.0183 & $-0.0312 * * *$ & -0.0102 & $-0.0265 * * *$ & $-0.0207^{* * *}$ & -0.0077 & $-0.0156 * *$ \\
\hline Life satisfaction squared/100 & 0.111 & $0.289 * * *$ & 0.0484 & $0.199 * * *$ & $0.165^{* * *}$ & 0.0614 & $0.125^{* *}$ \\
\hline \multicolumn{8}{|l|}{ Life satisfaction } \\
\hline Turning point & - & 5.40 & - & 6.66 & 6.27 & - & 6.24 \\
\hline Sub-sample average & 5.26 & 5.32 & 4.49 & 5.38 & 6.02 & 5.20 & 6.89 \\
\hline $\mathrm{R}^{2}$ & 0.061 & 0.076 & 0.044 & 0.050 & 0.031 & 0.049 & 0.022 \\
\hline Observations & 2,014 & 7,857 & 2,470 & 5,560 & 4,462 & 3,918 & 4,209 \\
\hline Number of countries & 3 & 9 & 3 & 6 & 5 & 4 & 5 \\
\hline
\end{tabular}

Notes: $* * * \mathrm{p}<0.01,{ }^{* *} \mathrm{p}<0.05,{ }^{*} \mathrm{p}<0.1$. Robust standard errors, clustered at locality level, used to calculate regressors' statistical significance. Full econometric output available on request.

\section{ADDRESSING ENDOGENEITY}

One of the objectives of this study is to deal with the potential endogeneity of the life satisfaction variable and try to establish the effect of life satisfaction on emigration intentions. Endogeneity problems may arise if preparation for migration temporarily renders people more or less happy relative to their underlying, long-term levels of happiness. For example, a prospective migrant, anticipating separation from friends and family, may become sad or anxious and report a level of subjective wellbeing that is lower than she would normally report in the absence of emigration intentions. Some evidence for this comes from the internal migration literature: Nowok et al. (2013) find that internal migrants in the UK experience a significant fall in life satisfaction just before the move; life satisfaction, however, returns to initial levels when the move takes place and remains at these levels thereafter. If preparing to move within a country makes people less happy, there is good reason to believe that preparing to move abroad has the same, if not larger, negative effects on subjective well-being.

Endogeneity can also arise due to unobserved variables. Changes in personal circumstances, such as the deterioration of relationships with family members or problems at work, can make people think about moving abroad and, at the same time, temporarily reduce their happiness. Large-scale surveys rarely collect information on such specific changes in 
respondents' lives, meaning that these characteristics cannot be accounted for in crosssectional analyses. Therefore, it cannot be ruled out that the association between happiness and willingness to migrate is driven by unobserved factors.

In the absence of data that would allow tracing prospective migrants' subjective well-being over time, one way to establish the effects of is to use instrumental variable analysis. The method relies on the availability of instruments which are relevant (highly correlated with life satisfaction) and exogenous (affecting emigration intentions only through life satisfaction). Ideally, I want the instruments to predict the long-term, underlying component of one's life satisfaction. Arguably, such long-term trends in subjective well-being can be traced back to respondents' childhood environments. As the LITS-2 survey contains some information on respondents' parents and other family members, I explore this information to construct the instruments.

The first instrument candidate is parental years of education. One could argue that, other things equal, more educated parents are more responsive to the emotional needs of their children, which, in turn, has a positive long-term effect on the children's subjective wellbeing. This said, it is also possible that more educated parents are busier and more careeroriented than their less educated counterparts, which might result in less time spent with children and less attention paid to the children's emotional needs. The conjecture that more educated parents spend less time with their children is not supported by evidence (Guryan et al., 2008). There is also some evidence that parental education enhances children's psychological well-being (see, e.g., Konu et al. (2002) and Videon (2005)). Against this backdrop, I expect parental schooling to be positively correlated with the respondents' life satisfaction. In practical terms, respondents were asked about the level of schooling (completed years of education) of their mother and father. I chose father's years of education, as it had higher predictive power in the first stage regression than mother's schooling.

The second instrument candidate captures the fact that a respondent's family member was a victim of World War II (WWII). It is based on the question "Were you, your parents or any of your grandparents physically injured or killed during the Second World War?” Frey (2012) discusses various channels through which wars can affect the well-being of soldiers and their family members. On the one hand, one would naturally expect wars to reduce happiness; there is ample evidence that soldiers returning from wars are more likely to suffer from posttraumatic stress disorder, depression, and alcohol and drug abuse, as well as to commit crime, 
violence and suicide. ${ }^{14}$ However, Frey (2012) also argues that wars can increase happiness of soldiers and their family members. In retrospect, soldiers and victims of war may reconsider their war experience in a positive light because they are happy to have survived (the 'afterglow' effect). Fighting in wars may result in feelings of shared purpose, solidarity, trust, friendship and national pride, all of which could enhance happiness. Many wars, including WWII, were proclaimed as serving a desirable goal, and family members may not mourn and actually be proud that someone in their family died as a 'martyr' or was fighting for a 'good' or 'holy' cause. It is, thus, possible that people fighting for, and affected by, such 'ennobling' wars “convert the costs of war into psychic benefits” (Frey, 2012, p.369).

Considering the post-socialist countries, which constitute the majority of the sample in the current study, WWII played a crucial role in the political discourse and ideology, and the formation of national identities. The victims of WWII, ${ }^{15}$ surviving soldiers and civilians who suffered during the war were venerated as heroes. WWII occupied a prominent place in the minds of ordinary citizens: it was a major life event for people who were engaged in it, and the war memories were - and continue to be - passed through generations. Thus, the children and grandchildren of people who were killed, injured or suffered during WWII had all the reasons to be proud about the heroic past of their family members. In socialist times, they enjoyed different forms of societal and institutional respect and attention, and were exposed to (often ennobled) family stories of war hardships, survivals and deaths. All these factors may have had a positive effect on the psychological development and well-being of the WWII victims' descendants, and one can expect that, today, these people report higher levels of subjective well-being relative to people in similar circumstances but without the presence of WWII 'heroes' in the family.

To test whether the instruments are relevant, the F test of the joint significance of excluded instruments will be conducted after the first stage regression. A value higher than a commonly accepted threshold of 10 would indicate that instruments are sufficiently strong predictors of life satisfaction. In addition, I expect each instrument to be individually significant in the first stage regression.

To test whether the instruments are exogenous, I will use the instrument over-identification test. It, however, rests on the assumption that at least one instrument is exogenous.

\footnotetext{
${ }^{14}$ See Frey (2012) for an overview of this literature.

${ }^{15}$ For the Soviet Union alone, the WWII death toll exceeded 20 million people (Ellmann and Maksudov, 1994).
} 
Considering the exogeneity of the WWII instrument, it is difficult to come up with explanations, apart from the proposed life satisfaction channel, of why the fact that someone was killed or injured during WWII would affect emigration intentions of his/her descendants more than sixty years later. ${ }^{16}$ The exogeneity of the parental education instrument is more questionable. More educated people have a greater chance of studying abroad and might have explicit strategies of preparing their children for emigration, such as investing in their foreign language skills. Also, children of more educated parents might have more experience of travelling and higher (unobserved) innate ability, both of which might affect emigration propensity. The over-identification test will thus question the exogeneity of the parental education instrument and assume that the WWII instrument is valid.

Despite the binary nature of the dependent variable, I estimate the instrumental variable model with the two stage least squares. The linear IV model is preferred to the IV probit estimation, as the latter does not produce all the instrument validity tests ${ }^{17}$ and the results of the linear model are easier to interpret. As a robustness check, an IV probit model has also been estimated; the results are qualitatively similar to the results of the corresponding linear models and are available on request.

The instrumental variable results are reported in Table 5. The first-stage results (column 1) suggest that the instruments are individually statistically significant and have the expected signs: other things equal, both father's schooling and having a relative who was either killed or injured in WWII are positively and significantly correlated with life satisfaction. The relevance of the instruments is confirmed by the $\mathrm{F}$ test value of 12.12, which is higher than the threshold value of 10 . The insignificant statistic of the overidentification test $(0.35)$ suggests that the instruments are exogenous. The tests, thus, support the appropriateness of the chosen instruments.

\footnotetext{
${ }^{16}$ One could argue that WWII victims have experience of crossing international borders, the impressions of which could then be passed to future generations and influence their intentions to migrate. Note, however, that the question, used to construct the instrument, asks about the family members who were killed or injured during WWII. People killed during the war by definition would not be able to pass stories about visiting other countries (but family members could still gain in happiness through societal respect). As for the injured, they would be less likely to cross international borders unless they were injured in a foreign country, and would probably put a greater weight on the survival/injury aspect of the WWII experience. Note also that the question refers to both military and civilian victims of WWII. The latter would have a much lower likelihood of visiting foreign countries during the war (unless they were international war refugees). Unfortunately, the data do not allow separating victims who were killed from those who were injured, as well as soldier victims from civilian victims.

${ }^{17}$ For example, the ivprobit command in Stata does not include the instrument overidentification test. See also Ivlevs and King (2012) for a discussion of testing instrument exogeneity in non-linear models.
} 
The second-stage results (columns 2) show that life satisfaction exerts a positive and statistically significant effect on the probability of reporting intentions. Moving up one step on the life satisfaction scale increases the probability of reporting intentions by 14 percentage points. This relatively large, in terms of magnitude, effect counters the correlational evidence of this and other studies, which point at a U-shaped or a negative association between the subjective well-being and desire to emigrate. This discrepancy could be explained by reverse causality, whereby preparation for migration temporarily reduces subjective well-being. It is also possible that the bias is due to unobserved variables: for example, sudden problems with one's job or a deterioration of relationships in one's family - factors which are generally not taken into account in correlational cross-sectional studies - would both reduce subjective well-being and increase the desire to migrate. 
Table 5. Life satisfaction and intentions to move abroad, 2SLS results

\begin{tabular}{|c|c|c|}
\hline & $\begin{array}{c}\text { First stage } \\
\text { Dependent variable: } \\
\text { Life satisfaction } \\
\end{array}$ & $\begin{array}{c}\text { Second stage } \\
\text { Dependent variable: } \\
\text { Intentions to move abroad }\end{array}$ \\
\hline Life satisfaction (1 - low, ... 10 - high) & - & $0.140 * * *$ \\
\hline Female & $0.093 * * *$ & $-0.042 * * *$ \\
\hline \multicolumn{3}{|l|}{ Age group } \\
\hline $18-24$ & $0.261 * * *$ & -0.019 \\
\hline $25-34$ & 0.038 & 0.002 \\
\hline $35-44$ & Ref. & Ref. \\
\hline $45-54$ & 0.009 & $-0.015 * *$ \\
\hline $55-64$ & $0.233^{* * *}$ & $-0.050 * * *$ \\
\hline \multicolumn{3}{|l|}{ Marital status } \\
\hline Single & $-0.065 *$ & $0.037 * * *$ \\
\hline Married/ relationship & Ref. & Ref. \\
\hline Divorced/separated & $-0.268 * * *$ & $0.054 * * *$ \\
\hline Widow & $-0.242 * * *$ & $0.043^{* * *}$ \\
\hline Has children & $0.067 * *$ & $-0.011 *$ \\
\hline Linguistic minority & $-0.112 *$ & $0.043 * * *$ \\
\hline \multicolumn{3}{|l|}{ Education } \\
\hline Primary & $-0.082 * *$ & $0.014^{*}$ \\
\hline Secondary & Ref. & Ref. \\
\hline Tertiary & $0.130 * * *$ & $-0.020 * *$ \\
\hline Wealth index & $0.137 * * *$ & $-0.015^{* * *}$ \\
\hline Perceived income decile (1 - low.. 10 - high) & $0.319 * * *$ & $-0.046^{* * *}$ \\
\hline Satisf. with financ. situation ( 1 - low.. 5 - high) & $0.418 * * *$ & $-0.063^{* * *}$ \\
\hline Employed & 0.032 & $-0.010 *$ \\
\hline \multicolumn{3}{|l|}{ Type of settlement } \\
\hline Rural & 0.010 & -0.002 \\
\hline Urban & Ref. & Ref. \\
\hline Metropolitan & 0.031 & -0.008 \\
\hline \multicolumn{3}{|l|}{ Health } \\
\hline Bad & $-0.342 * * *$ & $0.047 * * *$ \\
\hline Medium & Ref. & Ref. \\
\hline Good & $0.262 * * *$ & $-0.035^{* * *}$ \\
\hline Migrant networks & $-0.072 *$ & $0.039 * * *$ \\
\hline Country fixed effects & Yes & Yes \\
\hline \multicolumn{3}{|l|}{ Instruments: } \\
\hline Father's years of education & $0.017 * * *$ & \\
\hline Family member killed or injured in WWII & $0.071^{* *}$ & \\
\hline F test of excluded instruments & 12.12 & \\
\hline Overidentification test (Hansen J stat p-value) & 0.35 & \\
\hline Regressor endogeneity test (p-value) & & 0.000 \\
\hline Observations & & 24,070 \\
\hline
\end{tabular}

Notes: ${ }^{* * *} \mathrm{p}<0.01,{ }^{* *} \mathrm{p}<0.05,{ }^{*} \mathrm{p}<0.1$. Robust standard errors, clustered at the locality level, used to calculate regressors' statistical significance. 


\section{ROBUSTNESS AND SENSITIVITY CHECKS}

In the first robustness check, I use a question on willingness to migrate ("Would you be willing to move abroad for employment reasons?”), rather a question on emigration intentions (“Do you intend to move abroad in the next 12 months?”), to capture emigration decision. The results are largely consistent with the emigration intentions specifications: in the whole-sample linear model, life satisfaction is a negative and insignificant correlate of the willingness to migrate; in the quadratic model, the association between life satisfaction and willingness to migrate is U-shaped and highly significant (the turning point is 6.02 ); ${ }^{18}$ in the instrumental variable estimation, life satisfaction also appears to have a positive impact on willingness to migrate.

Second, I exclude from the analysis control variables capturing satisfaction with financial situation and subjective health (these variables are considered to be important components of life satisfaction and, if included as controls, can reduce the variation in the main regressor). The correlational results remain qualitatively unchanged. The only difference in the instrumental variable estimation is that the overidentification test now is not passed. This suggests that the instruments influence emigration intentions through channels other than life satisfaction, and such channels could well be the excluded controls. For example, parental education may affect children's physical health and (satisfaction with) financial situation which, in turn, may affect emigration intentions.

Third, I note that the sample size in the 2SLS estimation is about four fifths of the sample size in the OLS estimations. This is because 24 percent of the respondents did not provide an answer to the question on father's education and had to be excluded from the 2SLS estimations. Such a high non-response rate could bias the instrumental variable results. I check whether selection bias is present in the OLS estimations which exclude respondents who did not provide an answer on their father's education. Using a Heckman correction model, where the non-response on mother's education serves as identification variable for providing an answer on father's education, I find no evidence that that selection bias is present. This is confirmed by virtually the same results of the estimations which exclude respondents who did not report the education of their father and the corresponding full-

\footnotetext{
${ }^{18}$ The U-shaped relationship is prevalent across countries with different levels of income per capita and institutional quality. Among country groups, the U-shaped relationship is observed in the Balkans, Central Europe, rest of the ex-USSR, and Western Europe.
} 
sample estimations presented in Table 1.

In a final robustness check, I included in the instrumental variable estimation a control variable capturing family connections to the former communist party (this estimation was conducted for the subsample of the post-socialist countries only). Former party connections could be linked to specific networks which might have been transferred over time and could facilitate migration or find work at home today. As highly educated people were more likely to be party members, they could affect their children's emigration decision through party connections. The communist party channel may also be an issue for the WWII instrument, if the party members were more likely to fight in the war or if the party explicitly targeted the WWII veterans to become its members. The results are robust to the inclusion of the communist party control.

\section{CONCLUSION}

This paper has studied how people select into migration on the basis of life satisfaction in 35 European and Central Asian countries. The results suggest a U-shaped association between life satisfaction and emigration intentions: very life-satisfied and very life-unsatisfied people are the most likely to say that they intend to move abroad in the following year, while people close to the middle of the life satisfaction distribution are the least likely to do so. National income per capita, institutional quality and different geo-political and cultural contexts appear to have little influence on this finding.

The paper has also attempted to deal with the potential endogeneity of the life satisfaction variable and estimate the effect of life satisfaction on emigration intentions. The instrumental variable analysis revealed that higher levels of life satisfaction contribute to a higher probability of reporting intentions to move abroad. This result is in conflict with much of the previous literature reporting a negative association between subjective well-being and the emigration decision. As such, it should be disturbing news for policymakers in migrantsending countries. Recent evidence suggests that higher levels of subjective well-being make people more productive, creative, healthy and sociable. The outflow of happy people 'happiness drain' - would deprive migrant-sending countries of these positive externalities of 
happiness. ${ }^{19}$ On the other hand, the positive selection of migrants on the basis of subjective well-being should be good news in migrant-receiving countries. Happier, hence more productive, healthy and sociable migrants, are likely to put less pressure on the welfare state and integrate easier into host societies, compared to the situation where migrants were negatively selected on subjective well-being.

Several notes of caution, however, have to be made. First, this paper has concentrated on a specific part of the world (post-socialist and select Western European countries) and used data for one year to identify the effect of life satisfaction on emigration intentions. There is no guarantee the results are generalizable to other contexts. More empirical work, dealing with endogeneity as well as other parts of the world, should be undertaken to provide a more reliable picture of the effects of happiness on the emigration decision. Second, the intentions to emigrate not always translate into actual moves. ${ }^{20}$ 'Dreaming' about emigration expressing desire to migrate which is never followed by actual migration - may well be a characteristic of a happy person. Unfortunately, the cross-sectional sending-country survey data by definition cannot not contain information on both the subjective well-being and actual moves of the same people (actual migrants cannot be observed in sending countries); panel data are necessary to answer the question of whether happy people are more likely to be 'dreamers' or actual 'movers'. Third, even if it is the happiest people who are more prone to emigration in sending countries, their level of subjective well-being may still remain below that of people in the host society. Under such circumstances, the benefits of high subjective well-being in terms of greater productivity, health and sociability may not fully materialise. It is also possible that migration experience makes people less happy (e.g. Bartram, 2010). If this is the case, the happiness capital that migrants bring with them into the host society, and the associated long-term benefits, may erode. An ambitious data collection effort, which, for a particular migration episode, would involve both origin and destination countries and follow the same migrants over time, is necessary to provide a more comprehensive view of the happiness-migration nexus.

\footnotetext{
${ }^{19}$ The increasing portion of the U-shaped association between life satisfaction and emigration intentions obtained in the correlational analysis would also support the existence of 'happiness drain'.

${ }^{20}$ The existing evidence on the link between willingness/ intentions to migrate and the actual move is available for the UK (Boheim and Taylor, 2002), the Netherlands (van Dalen and Henkens, 2013) and Mexico (Creighton, 2013). It is unclear how strong this link is in the post-socialist countries of Eastern Europe and Central Asia.
} 


\section{REFERENCES}

Akay, Alpaslan, Amelie Constant and Corrado Giulietti (2014). The impact of immigration on the wellbeing of natives, Journal of Economic Behavior and Organization. 103: 72-92.

Amabile, Teresa, Sigal Barsade, Jennifer Mueller and Barry Staw (2005). Affect and creativity at work, Administrative Science Quarterly. 50: 367-403.

Bartram, David (2010). International migration, open borders debates, and happiness. International Studies Review 12, 339-361.

Bartram, David (2011). Economic Migration and Happiness: Comparing Immigrants' and Natives’ Happiness Gains from Income. Social Indicators Research, 103(1): 57-76.

Bartram, David (2013). Happiness and 'economic migration': A comparison of Eastern European migrants and stayers. Migration Studies 1 (2): 156-175.

Betz, William, and Nicole B. Simpson (2013). The Effects of International Migration on the Well-Being of Native Populations in Europe. IZA Journal of Migration 2:12.

Böheim, Rene, and Mark P. Taylor (2002). Tied down or room to move? Investigating the relationships between housing tenure, employment status and residential mobility in Britain. Scottish Journal of Political Economy, 49 (4): 369-392.

Boneva, Bonka, and Irene H. Frieze (2001). Toward a Concept of Migrant Personality. Journal of Social Issues 57(3): 477-491.

Borraz, Fernando, Maximo Rossi and Susan Pozo (2008). And What About the Family Back Home? International Migration and Happiness. Working Paper, Universidad de la Republica, Documento No. 03/08.

Burda, Michael, Wolfgang Hardle, Marlene Muller and Axel Werwatz (1998). Semiparametric Analysis of German East-West Migration Intentions: Facts and Theory. Journal of Applied Econometrics, 13(5): 525-541.

Cai, Ruohong, Neli Esipova, Michael Oppenheimer and Shuaizhang Feng (2014). International migration desires related to subjective well-being. IZA Journal of Migration, 3:8

Chindarkar, Namrata (2014). Is subjective well-being of concern to potential migrants from Latin America? Social Indicators Research, 115(1):159-182

Clark, Andrew, Paul Frijters and Michael Shields (2008). Relative income, happiness and utility: an explanation for the Easterlin paradox and other puzzles, Journal of Economic Literature, 46(1): 95-144.

Creighton, Mathew J. (2013). The role of aspirations in domestic and international migration. Social Sciences Journal, 50(1):79-88.

Dalen, Hendrik P. van, and Kene Henkens (2013). Explaining Emigration Intentions and Behaviour in the Netherlands, 2005-10, Population Studies 67(2): 225-241

De Jong, Gordon F. (1999). Choice Processes in Migration Behavior. In Pandit, K. \& Withers S.D. (eds.), Migration and Restructuring in the United States. New York, NY: Rowman and Littlefield.

De Jong, Gorgon F. (2000). Expectations, gender, and norms in migration decision making. Population Studies 54(3), 307 - 319 
De Neve, Jan-Emmanuel, Ed Diener, Louis Tay and Cody Xuereb (2013). The Objective Benefits of Subjective Well-Being. In Helliwell, John, Richard Layard and Jeffrey Sachs (eds.) World Happiness Report 2013. New York: UN Sustainable Development Solutions Network.

De Neve, Jan-Emmanuel, and Andrew Oswald (2012). Estimating the influence of life satisfaction and positive affect on later income using sibling fixed effects. PNAS: Proceedings of the National Academy of Sciences 109(49): 19953-19958.

Di Tella, Rafael, and Robert MacCulloch (2006). Some Uses of Happiness Data in Economics, Journal of Economic Perspectives, 20(1): 25-46.

Diener, Ed, and Micaela Y. Chan (2011). Happy people live longer: Subjective well-being contributes to health and longevity, Applied Psychology: Health and Well-Being 3(1): 1-43.

Diener, Ed, Ronald Inglehart and Louis Tay (2012). Theory and validity of life satisfaction scales. Social Indicators Research 112(3):497-527

Diener, Ed, Richard Lucas, Ulrich Schimmack, John Helliwell (2009). Well-being for public policy. New York: Oxford University Press.

DNB Banka (2013). DNB Latvijas Barometrs Nr. 58: Emigrācija [DNB Latvia Barometer Nr.58: Emigration]. Riga: DNB Banka.

Drnovsek, Marjan (2009). Fragments from Slovenian Migration History, 19th and 20th Centuries. In Brunnbauer, Ulf (Ed.): Transnational Societies, Transterritorial Politics. Migrations in the (Post-)Yugoslav Region, 19th-21st Century. Munich: R. Oldenbourg Verlag.

Ek, Ellen, Markku Koiranena, Veli-Pekka Raatikkaa, Marjo-Riitta Järvelinc and Anja Taanila (2008) Psychosocial factors as mediators between migration and subjective wellbeing among young Finnish adults. Social Science \& Medicine, 66(7): 1545-56.

Ellman, Michael, and Sergei Maksudov (1995). Soviet deaths in the great patriotic war: A note. Europe-Asia Studies 46(4): 671-680.

Erlinghagen, Marcel (2011). Nowhere Better Than Here? The Subjective Well-Being of German Emigrants and Remigrants. Comparative Population Studies, 36(4): 899926.

Frey, Bruno (2012). Well-being and war. International Review of Economics, 59: 363-375.

Frey, Bruno and Alois Stutzer (2002). What Can Economists Learn from Happiness Research? Journal of Economic Literature, 40(2):402-35.

George, Jennifer M., and Jing Zhou (2007). Dual tuning in a supportive context: Joint contributions of positive mood, negative mood, and supervisory behaviors to employee creativity. Management Journal 50: 605-622.

Graham, Carol (2009). Happiness around the World: The Paradox of Happy Peasants and Miserable Millionaires. Oxford: Oxford University Press.

Graham, Carol, and Julie Markowitz (2011). Aspirations and Happiness of Potential Latin American Immigrants. Journal of Social Research and Policy 2(2): 9-25.

Guryan, Jonathan, Erik Hurst and Melissa Kearney (2008). Parental Education and Parental Time with Children. The Journal of Economic Perspectives 22(3): 23-46.

Guven, Cahit (2011). Are Happier People Better Citizens? Kyklos 64 (2): 178-192. 
Headey, Bruce (2010). The Set Point Theory of Well-Being Has Serious Flaws: On the Eve of a Scientific Revolution? Social Indicators Research 97: 7-21.

Helliwell, John, and Christopher Barrington-Leigh (2010). Viewpoint: Measuring and Understanding Subjective Well-Being. Canadian Journal of Economics, 43(3): 729753.

Helliwell, John, Richard Layard and Jeffrey Sachs (Eds.). (2013). World happiness report. New York: UN Sustainable Development Solutions Network.

International Organization for Migration (2013). World Migration Report 2013: Migrant Well-Being and Development. Geneva

Ivlevs, Artjoms (2013). Minorities on the move? Assessing post-enlargement emigration intentions of Latvia's Russian speaking minority, Annals of Regional Science 51(1): 33-52.

Ivlevs, Artjoms (2014). Happiness and the Emigration Decision. IZA World of Labor 2014: 96. Available at http://wol.iza.org/articles/happiness-and-the-emigration-decision

Ivlevs, Artjoms, and Roswitha King (2012). Does more schooling make you run for the border? Evidence from post-independence Kosovo. Journal of Development Studies 48(8):1108-1120.

Konu, Anne, Tomi Lintonen and Matti Rimpela (2002). Factors associated with schoolchildren's general subjective well-being. Health Education Research 17 (2): 155-165.

Layard, Richard (2005). Happiness: Lessons from a New Science. London: Penguin.

Liebig, Thomas, and Alfonso Sousa-Poza (2004). Migration, self-selection and income inequality: an international perspective, Kyklos 57(1): 125-146.

MacKerron, George (2012). Happiness economics from 35,000 feet. Journal of Economic Surveys, 26 (4): 705-735.

Nikolova, Milena, and Carol Graham (2015). In transit: the well-being of migrants from transition and post-transition countries. Journal of Economic Behavior and Organization 112: 164-186.

Nowok, Beata, Maarten van Ham, Allan M. Findlay and Vernon Gayle (2013). Does migration make you happy? A longitudinal study of internal migration and subjective well-being. Environment and Planning A 45(4): 986-1002.

OECD. (2013). Guidelines on measuring subjective well-being. Paris: OECD. Retrieved from http://www.oecd.org/statistics/Guidelines on Measuring Subjective Well-being.pdf

Office for National Statistics (2013). Personal Well-being in the UK, 2012/13. United Kingdom: Office for National Statistics.

Oishi, Shigehiro, Ed Diener, Richard Lucas and Eunkook Suh (1999). Cross-Cultural Variations in Predictors of Life Satisfaction: Perspectives from Needs and Values. Personality and Social Psychology Bulletin, 25(8): 980-90.

Oswald, Andrew, Eugenio Proto and Daniel Sgroi (2015). Happiness and productivity. Journal of Labor Economics, forthcoming.

Polgreen, Linnea, and Nicole Simpson (2011). Happiness and International Migration. Journal of Happiness Studies 12(5): 819-840. 
Otrachshenko, Vladimir, and Olga Popova (2014). Life (Dis)Satisfaction and the Intention to Migrate: Evidence from Central and Eastern Europe. Journal of Socio-Economics 48: 40- 49 .

Simpson, Nicole (2013). Happiness and Migration. In International Handbook on the Economics of Migration. Editors: Klaus F. Zimmermann and Amelie F. Constant, Edward Elgar Publishing Limited.

Stark, Oded, and J. Edward Taylor (1991). Migration Incentives, Migration Types: The Role of Relative Deprivation. The Economic Journal 101(408): 1163-78.

Stillman, Steven, John Gibson, David McKenzie and Halahingano (2015). Miserable Migrants? Natural Experiment Evidence on International Migration and Objective and Subjective Well-Being. World Development 65: 79-93.

Videon, Tami (2005). Parent-Child Relations and Children's Psychological Well-Being. Do Dads Matter? Journal of Family Issues 26(1): 155-78. 


\section{$\underline{\text { Appendix }}$}

SUMMARY STATISTICS OF THE VARIABLES INCLUDED IN THE ANALYSIS

Table A1. Summary statistics

\begin{tabular}{|c|c|c|c|c|c|}
\hline & Obs. & Mean & St.dev. & Min & Max \\
\hline Intentions to emigrate & 30567 & 0.048 & 0.214 & 0 & 1 \\
\hline Life satisfaction ( 1 - low, ... 10 - high) & 30567 & 5.581 & 2.090 & 1 & 10 \\
\hline Female & 30567 & 0.597 & 0.491 & 0 & 1 \\
\hline \multicolumn{6}{|l|}{ Age group } \\
\hline $18-24$ & 30567 & 0.140 & 0.347 & 0 & 1 \\
\hline $25-34$ & 30567 & 0.234 & 0.423 & 0 & 1 \\
\hline $35-44$ & 30567 & 0.228 & 0.420 & 0 & 1 \\
\hline $45-54$ & 30567 & 0.212 & 0.409 & 0 & 1 \\
\hline $55-64$ & 30567 & 0.186 & 0.389 & 0 & 1 \\
\hline \multicolumn{6}{|l|}{ Marital status } \\
\hline Single & 30567 & 0.226 & 0.418 & 0 & 1 \\
\hline Married/ relationship & 30567 & 0.623 & 0.485 & 0 & 1 \\
\hline Divorced/ separated & 30567 & 0.098 & 0.297 & 0 & 1 \\
\hline Widow & 30567 & 0.053 & 0.224 & 0 & 1 \\
\hline Has children & 30567 & 0.429 & 0.495 & 0 & 1 \\
\hline Linguistic minority & 30567 & 0.123 & 0.328 & 0 & 1 \\
\hline \multicolumn{6}{|l|}{ Education } \\
\hline Primary & 30567 & 0.260 & 0.438 & 0 & 1 \\
\hline Secondary & 30567 & 0.524 & 0.499 & 0 & 1 \\
\hline Tertiary & 30567 & 0.216 & 0.412 & 0 & 1 \\
\hline Wealth index & 30567 & 0.219 & 1.757 & -2.711 & 3.328 \\
\hline Perceived income decile (1 - low.. 10 - high) & 30567 & 4.515 & 1.674 & 1 & 10 \\
\hline Satisf. with financ. situation (1 - low.. 5 - high) & 30567 & 2.785 & 1.132 & 1 & 5 \\
\hline Employed & 30567 & 0.585 & 0.493 & 0 & 1 \\
\hline \multicolumn{6}{|l|}{ Type of settlement } \\
\hline Rural & 30567 & 0.399 & 0.490 & 0 & 1 \\
\hline Urban & 30567 & 0.474 & 0.499 & 0 & 1 \\
\hline Metropolitan & 30567 & 0.128 & 0.334 & 0 & 1 \\
\hline \multicolumn{6}{|l|}{ Health } \\
\hline Bad & 30567 & 0.085 & 0.280 & 0 & 1 \\
\hline Medium & 30567 & 0.310 & 0.463 & 0 & 1 \\
\hline Good & 30567 & 0.605 & 0.489 & 0 & 1 \\
\hline Migrant networks & 30567 & 0.138 & 0.345 & 0 & 1 \\
\hline Father's years of education & 24070 & 9.683 & 4.115 & 0 & 50 \\
\hline Family member killed or injured in WWII & 30567 & 0.238 & 0.426 & 0 & 1 \\
\hline
\end{tabular}


World Bank classification of countries included in the analysis by income per capita (2010)

Low-income

Kyrgyzstan, Tajikistan

Lower middle-income

Albania, Armenia, Georgia, Moldova, Mongolia, Ukraine, Uzbekistan, Kosovo

Upper middle-income

Azerbaijan, Belarus, Bosnia-Herzegovina, Bulgaria, Kazakhstan, Latvia, Lithuania,

FYR Macedonia, Romania, Russia, Serbia, Turkey, Montenegro

\section{High-income}

Croatia, Czech Republic, Estonia, France, Germany, Hungary, Italy, Poland, Slovakia, Slovenia, Sweden, UK

Classification of countries included in the analysis by institutional quality (based on the World Bank World Governance Indicators)

Low-quality institutions

Azerbaijan, Belarus, Kazakhstan, Kyrgyzstan, Russia, Tajikistan, Ukraine, Uzbekistan Lower middle-quality institutions

Albania, Armenia, Bosnia-Herzegovina, Georgia, FYR Macedonia, Moldova, Mongolia, Serbia, Kosovo

Upper middle-quality institutions

Bulgaria, Croatia, Italy, Latvia, Lithuania, Poland, Romania, Turkey, Montenegro High-quality institutions

Czech Republic, Estonia, France, Germany, Hungary, Slovakia, Slovenia, Sweden, UK 